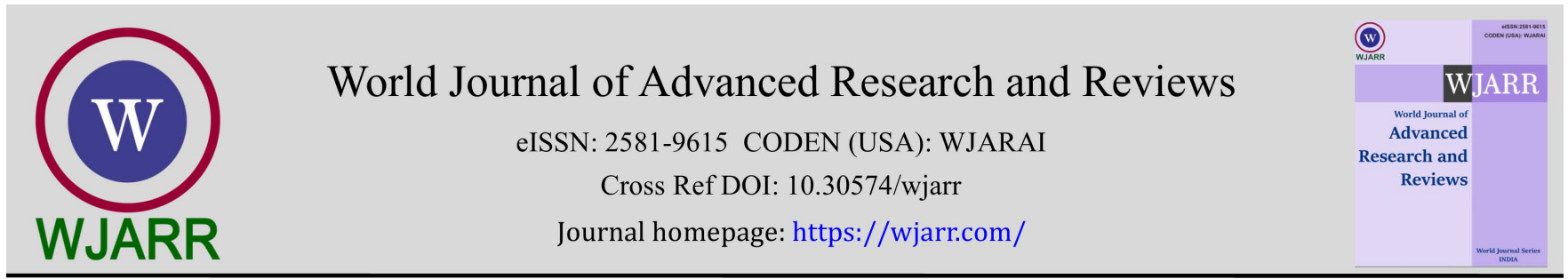

(RESEARCH ARTiClE)

\title{
Factors determining household savings in Zambia: A logit regression model from the micro-economic perspective
}

\author{
Saviour Lusaya ${ }^{1, *}$ and Namoonga Mulunda ${ }^{2}$ \\ ${ }^{1}$ University of Zambia, Lusaka, Zambia. \\ 2 Information and Communications University Lusaka, Zambia.
}

World Journal of Advanced Research and Reviews, 2022, 13(01), 520-533

Publication history: Received on 04 December 2021; revised on 10 January 2022; accepted on 12 January 2022

Article DOI: https://doi.org/10.30574/wjarr.2022.13.1.0007

\begin{abstract}
Although not directly linked in time and space, the low savings in an economy will pose a huge challenge on the growth prospect of the country as both private and public savings remain catalytic to economic growth. The classical and neoclassical growth theories have placed emphasis on the critical role of savings in the economy and indeed the need for high savings cannot be overemphasised. This study sought to examine microeconomic determinants of household savings in Zambia using cross sectional data obtained from the Central Statistics Office 2015 Living Condition Monitoring Survey comprising 12251 households. The study conducted an analysis of factors using a Logistic regression model. The results of the study found that income and employment status of the households had a positive and significant influence on the probability of a household to save. On the other hand, household size, age and region (living in urban areas) negatively influenced household savings and was significant at all critical levels.

The marginal effects which measures the magnitude of the impact of the independent variable on the independent variable was analyzed and it was found that for income ceteris paribus, a 1\% increase in income was found to increase the probability of a household to save by 0.01 percentage point while an improvement in employment of household heads increases the probability of a household to save by5.6 percentage point ceteris paribus. Furthermore, ceteris paribus, an additional year of the household head age reduces the likelihood to save by 1.4 percentage point. On the basis of household size, the study found that ceteris paribus, adding an extra person to a given household reduces the likelihood of a household to save by 1.14 percentage point. For the region variable, the study used rural region as a benchmark region to distinguish between urban and rural household propensity to save. It was found that households that were located in urban areas were $9.8 \%$ less likely to save compared to households located in rural areas. Given the findings above, it was concluded that low levels of savings in Zambia are attributed to; low household incomes, overgrowing informal sector and overpopulated households. It was recommended that the government should increase its funding towards economic empowerment to boost job creation which would enhance household income and reduce over dependency of household members.
\end{abstract}

Keywords: Logit; Age; Income; Household Size; Region; Employment status; Savings

\section{Introduction}

In the midst of tough global conditions and domestic challenges faced by many other countries, Zambia has continued to face slower growth rate since 2015 [1]. According to their analysis, raising revenue for economic recovery highlights the numerous challenges being faced by the country which include among others; tight liquidity and limited efforts and resolutions towards economic reforms that will promote and bring about economic diversification as means of achieving a favourable balance of trade.

\footnotetext{
${ }^{*}$ Corresponding author: Saviour Lusaya

University of Zambia, Lusaka, Zambia.

Copyright (C) 2022 Author(s) retain the copyright of this article. This article is published under the terms of the Creative Commons Attribution Liscense 4.0.
} 
The Zambian economy has to a large extent entirely dependent on copper as its major export commodity, which in real terms exhibit diminishing returns to scale hence, exposing the economy to several hardships and lack of economic growth. Gross Domestic Product was estimated at the rate of 3\% in 2016, before improving in 2017 to about $4 \%$ and in 2018 it was less than the estimated 4.2\%. The slow growth of the economy entails serious challenges for the economy. The performance of precursors of economic drive such as investments growth, capital formation, human productivity, agricultural output, energy and external balance among others, need therefore be evaluated. Although not directly linked in time and space, the low savings in an economy will pose a huge challenge on the growth prospect of the country as both private and public savings remain catalytic to economic growth. The classical and neo-classical growth theories have placed emphasis on the critical role of savings in the economy and indeed, it is undisputed fact that a country that has low levels of savings will have to depend on FDI and external debt contraction to boast it growth.

Zambia's development agenda has evolved around the National development Plans. The changes in policies have affected both macro and microeconomic factors including households. From the Jaws of colonialism, the Zambian government devised a development agenda dubbed "First National Development Plan". The First National Development Plan which was formulated two years after Zambia's independence had put emphasis on economic diversification from dependence on copper mining as the nation's largest employer and supplier of development resources. Some of the objectives of the National Plan was raising employment and monetary output per head while maintaining price stability and minimizing economic imbalances between rural and urban Zambia. It further emphasised on raising the nation's levels of education and management skills among citizens, coupled with the need to provide adequate and improved housing and the general level of social welfare [2]. During this period, figures from the World Bank financial statistics indicate that capital formation as percentage of GDP had fluctuated from $12.05 \%$ in $1964,25.08 \%$ in $1965,34.23 \%$ in $1966,33.96 \%$ in $1967,19.20 \%$ in $1968,38.25 \%$ in 1969 to $37.29 \%$ in 1970 . In terms of gross domestic savings, Zambia recorded a steady increase in domestic savings as a percentage of GDP rising from 36.09\% in 1964, 39.97\% in 1965, $44.36 \%$ in 1966, 40.38\% in 1967, 40.55\% in 1968 and 50.94\% in 1969. However, the country recorded a decline in Domestic savings as a percentage beginning from 1970 where it stood at $45.06 \%$. In terms of household consumption expenditure, the country saw a downward trend in household consumption expenditure as a percentage with $50.36 \%$ in 1964 , to $39.41 \%$ in 1970 .

The second national plan was developed in 1971 to cover the period 1972 to 1976 . This was a build-on to the earlier National development plan aimed at a self-sustaining Zambia for equal resources distribution across the country. With a frenzy of new Kaunda Philosophy of Humanism, the second National Development Plan main targets were food selfsufficiency and ensuring food security, encouraging import substitution coupled with a progressive decline in dependency on the mining industry for national economic output and growth with a re-cultivation of the call for employment generation as envisaged by in the First National Development Plan with heightened technical skills. [3] notes that, from the pre-independence to 1974, Zambia saved and invested in excess of 30 percent of GDP. Average per capita income grew at around 4 percent per annum. He further noted that this was one of the best growth performances in the world. However, beyond 1975, Zambia's savings rate collapsed and the average investment rate, although inflated by foreign aid, external borrowing, and the accumulation of arrears, fell below 20 percent of GDP. During this period, Zambia's average per capita income declined by 2.5 percent per annum and now Zambia a country which was free from civil strife and coups was ranked among the poor performing countries in the world [3]. The rise in the Gross Domestic saving during the early years of independence could largely be attributed to the positive contribution of the parastatals however, [3] observed that the saving rate was only a fraction of what it had been. And due poor performance of the economy in the mid 1970's, Zambia ceased being a country which generated large amounts of saving and investment while public and private consumption dominated the national expenditure.

The mid-1970 was marked as the period of economic turmoil for Zambia as the country was hit with economic shocks in the soaring of oils prices as well as slump in the prices of the major foreign exchange earner, copper. [3] adds that the problem was excarbated by Zambia's response to this shock by financing the imbalances rather than adjusting. He added that these failures were costly, the accumulated loss of national income, the large external debt, and the deadweight loss of unutilised and poorly utilised capital run into the billions of dollars. With the government remining committed to put in the country on the right track, the late 1970's saw the birth of yet another national development plan called "Third National Development Plan (TNDP)" the main objective of the TNDP (1979-1984) included; to consider generation of more and fuller employment as a major objective of development and to that end, to adopt technology which is labourintensive; paying due regard to factor endowment and social needs of the Zambian economy; to diversify the economic structure in order to reduce the economy's; dependence on copper and to undertake a crash economic programme of; promoting agriculture and industry based on use of local raw materials and the establishment of the necessary capital goods industries (GRZ, 1979). This plan however did not last longer as the government switched to Structural Adjustment Programmes (SAP) in 1983. According to [4] and [5], the government embarked on policies that focused on the reduction of aggregate domestic demand. A freeze was imposed on wages as well as on government employment. 
During the period 1981-1990 while Gross domestic savings declined considerably from 19.3\% of real GDP in 1980 to $3.8 \%$ of real GDP in 1989. [6] added that the accumulation of physical capital and of human capital development was identified as the two most important traditional macroeconomic drivers of economic growth in Zambia during these periods. And [1] recorded that Gross domestic savings declined from an average of 40.1\% of GDP p.a. during the period 1960-1970 to an average of 13.8\% of GDP p.a. during the period 1981-1990. According to [7] to support such radical market-oriented reforms, the Government reduced its expenditures considerably during the period 1991-2000. In 1993, the government of Zambia eliminated all government subsidies from its budget as well as reduced the real wage for civil servants. This was the end period for the Fourth National Development Plan (FNDP) which had inactively been operating between 1989 and 1993 itself. [8] note that Zambia's economic performance in the 1990's was very disappointing with a decline in formal employment sending many into informal employment, high rates of inflation, while export significantly by 30\% between 1990 and 1998 [8]. During this period, the World Bank statistics indicate fluctuations in the gross national savings a percentage of GDP averaging $8.03 \%$ of GDP. There was however, steady growth in the levels of gross national savings after 1998. However, as privatisation still at climax, the improvement in gross national savings can be attributed to improved fiscal position due to reduced formal labour force (central government, local government and parastatals), reduced subsidies and increased capital flow from the privatised assets as opposed to improvement in the general wellbeing of the masses. The period 2000 marked yet another era in Zambia. With the country classified as high indebted poor country, the prospect for growth and investment was shuttered. The privatised companies where no longer generating the much expected income if not closed and this ultimately affected the over performance of the economy. World Bank [9] adds that during the period 2000-2009, gross domestic savings as a percentage of Gross Domestic Product (GDP) averaged 17.2\%. This is lower than that of East Asian and Pacific countries. These recorded an average percentage share of $28.9 \%$ during the same period but further noted that, Zambia's performance during this period was slightly better than that of the Sub Saharan Africa region which recorded a percentage share of $16.3 \%$ during the same period. However, realisation of the country's vision 2030 and attainment of the FNDP, SNDP and 7NDP cannot be envisaged with low levels of savings both at micro and macro level. This view resonates with a thought put forward by [10] that Public sector savings are largely determined by the decisions of government and very little is known on its determinants. Therefore, when looking at the key challenges to domestic savings the focus should be on private savings.

The low levels of savings the country has been grappling with has mainly been attributed to a poorly functioning financial system. According to Melzer (2007), only 14\% of Zambians save with banks. In most areas, particularly rural ones, the low utilization of banking services is attributed to the lack of banking facilities. However, in areas where there is access to banking facilities, the main problem is the high cost of opening and maintaining a bank account (Melzer, 2007).

In realising the role of financial system in deposit mobilisation in particular and the economy in general, the government, through the Bank of Zambia introduced the National Financial Sector Development Policy. According to [11] the Policy provides a holistic approach for Government to offer strategic guidance and coordinate overall financial sector development initiatives in the country, with the aim of having a well-developed and inclusive financial system that supports efficient resource mobilization and investment for sustainable economic development. However, savings still remain low. The low levels of savings in the country could be seen as the motivation for the government to source for external finance. This has in the recent past resulted in skyrocketing of the external debt levels to about $36.5 \%$ of GDP in 2016 from 8.4\% of GDP in 2011 [12]. During this period, gross national savings fell gradually from about 34\% of GDP to $32.5 \%$ of GDP [13]. This means that by and large, the government has relied on external savings from countries whose savings levels are higher to finance its expenditure. The consequences of overreliance on external savings cannot be underestimated, it potentially reduces domestic capital formation through huge foreign debt repayments. However the savings levels in a country maybe, many economists have failed to build a consensus on what really determine savings rate or savings level in the country with some arguing that the main factors influencing household savings are specific to individuals (i.e. micro factors) and others arguing that it is those country specific factors (i.e. macro factors). Thus, a number of studies have been undertaken for instance, in line with the Permanent Income Hypothesis, many studies including that by [14], [15] and [16] have underscored the role of income in improving savings while other studies on micro factors in other countries such as Ghana, Pakistan and Nigeria have found that age, employment status and region significantly affect savings rate.

\subsection{Statement of a Problem}

Zambia has been experiencing low savings rates as a percentage of the GDP which stood at 4.2\% as at 2018 [11]. This posse a major challenge considering that savings form the major source of economic growth and increased investment through capital formation. Lack of sufficient savings in the economy lead to insufficient reserves held by the banks which ultimately cause higher interest rates thereby increasing the cost of borrowing and crowding out private investment. 
Many countries including Zambia have heavily relied on household savings as a source of nation's savings given that these countries run on fiscal deficits leading them to look to borrowing to finance public expenditure which fund comes from savings. However, [11] notes that Zambia, like many other countries has a poor saving culture. This situation potentially would lead to low gross savings. While there has been focus towards improved savings in Zambia, there numerous obstacles to household savings that include low interest rate on savings, high taxes, low personal income, employment status, education among many other factors as observed by [17]. In order to address the problem of low savings, there is need to address the incentives to savings for households and currently it remains unclear as to what factors determine household savings. It is for this reason that this study sought to investigate the microeconomic factors that influencing household savings in Zambia.

\subsection{Research Objectives}

\subsubsection{General Objective}

The main objective of this study was to investigate microeconomic factors that determine household savings in Zambia.

\subsubsection{Specific Objectives}

The specific objectives of the study included the following;

- To establish the impact of personal income on savings propensity

- To determine the effect of household size on the savings propensity of households

- To ascertain the impact of employment status on savings ability of households

- To find out the effect of region on savings ability of the households

\subsection{Research Hypotheses}

The study was guided by the following research hypotheses:

\subsubsection{Household Income and Savings}

In line with various postulates, this study expects a significant positive relationship between growth in personal income and growth in the savings. This can be summarized in the statement of hypothesis as below;

- $\mathrm{H}_{0}$ : An increase in household income will result in an increased probability of household to save

- $\mathrm{H}_{1}$ : An increase in household income will not increase the probability of household to save

\subsubsection{Household Size and Households Savings}

- $\mathrm{H}_{0}$ : An increase in household size will result in a decrease in the probability of a household to save

- $\mathrm{H}_{1}$ : An increase in household size will not result into decreased probability of the household to save.

\subsubsection{Employment rate and Household Savings}

- $\mathrm{H}_{0}$ : employment status will positively increase the probability of the household to save.

- $\mathrm{H}_{1}$ : employment status will not positively increase the probability of a household to save.

\subsubsection{Rural/Urban Region and Household Savings}

- $\mathrm{H}_{0}$ : Rural location of a household decreases the likelihood of a household to save

- $\mathrm{H}_{1}$ : Rural location of a household does not affect the probability of a household to save

\section{Literature review}

The focus on investigating microeconomic factors influencing household savings emanates from the fact that savings, in line with the Solow growth model is their role is capital formation and economic growth of the country. Thus, in this chapter, both theoretical and empirical studies are reviewed within the context of this study. 


\subsection{Theoretical Literature}

\subsubsection{The Life Cycle Hypothesis}

The Modigliani saving hypothesis is understood to be the key theory in explaining individual savings behaviour. This theory tends to establish individual tendency to save throughout their life time. The life cycle hypothesis need to be understood by the fact that an individual lives over a certain period of time. This life begins to when they are born up until they die. During this period, individual (not knowing how long they will live) will tend to alter their consumption behaviour by deciding to save now in order to smoothen their future consumption. In this case, individual's saving rate will increase when they are younger, working than when they are older, working. Implicitly, the LCH brings out three demographical factors influencing savings behaviour i.e. household income, employment status and age. It is then true, according to this theory that savings at one stage will be lower, increasing up to a certain stage and diminishes in the later stage. These stages could relate to early adulthood with lower income which is expected to increase during progression to medium adulthood at which savings are expected to be high and in the later adulthood when the individual need to save less and consume more. Thus, wrapping up this theory is in the writings of Modigliani in [18] that, households are assumed to amass assets during prime or working ages, and relies on them during retirement age. It is built on the premises that consumption and hence, saving in a specific point in time is determined by expectations about the individual's lifetime income.

\subsubsection{The Permanent Income Hypothesis}

The Permanent Income Hypothesis (PIH) is a clear thought propounded by Milton Friedman. While the LCH argues savings and consumption on the basis of a life cycle of an individual, Friedman, in his PIH argues on the basis of an individual's permanent income. This thought is also at variance with the Keynesian view that consumption and savings if a function of current income. According to the PIH as opined by [19], people will spend money at a level consistent with their expected long-term average income. The level of expected long-term income then becomes thought of as the level of "permanent" income that can be safely spent. He argues that a worker will save only if his or her current income is higher than the anticipated level of permanent income, in order to guard against future declines in income [19]. According to [20] on PIH, it is held that the consumer's income consists of temporary income and permanent income, whose influences on consumption behaviour and savings behaviour are different.

As savings is part of the income not consumed, [21] observes that savings can also be transitory and permanent where permanent saving arises from permanent income and transitory savings arises from transitory income. To elaborate this notion further, [22] examplifies this by stating that in the framework of the Permanent Income Hypothesis, a person is going to earn a certain amount of money in his lifetime, he'll smooth his spending over a career based off of his expectations, as opposed to bouncing wildly around as rises and salary increases come [22]. He further stated that on the other side of the scale is a near-retiree who usually at a relative high point in their income. With kids out of the house, they usually save quite a bit in the expectation that their future "income" will decrease significantly to their level of Social Security payments. A cautious near-retiree carefully saves money to avoid an income shock when he is no longer earning active income[22]. As the role of savings is to smoothen future consumption, [20] emphasises that in order to realize maximization of utility, the consumer actually consumes according to the level of income that can be gained in the long term. Thus, temporary and short-term income affects the consumption level only when its variation affects the expectation of permanent income. To this and in line with Friedman's view, it is conclusive that people's income consists of two parts: temporary income and permanent income and that only the permanent income affects people's consumption, so consumption is the steady function of permanent income [20].

The income hypothesis implies that households first accumulate and then dis-save. In accordance with the intergenerational aspect of life and since adults expect their children to support them in their old age; they may be little need for lump or retirement savings as a vehicle for transferring income between high and low income productivity phases of their life cycle. [23] opines that in such households, savings are a buffer against stochastic decrease in income asserts that such households dis-save as often as they save and do not accumulate assets over the long run and have on average very small asset holdings [23].

\subsection{Empirical Literature Review}

A number of empirical studies have been undertaken to breakdown and quantify the above stated theoretical literature. For instance, the LCH can be seen to incorporate demographic factors (i.e. household size, Age, gender, education etc.) of the household while the PIH and the Ramsey mathematical theory of savings can be seen to view income from the economic factors (income and employment status) perspective. Thus, various studies undertaken on these subjects are reviewed below. 
To start with, in establishing the relationship between household income and savings, [24] conducted a study on household savings behaviour in Pakistan on a sample 293 respondents selected using stratefied random sampling technique. Using a multivariate regression technique in which household income was one of the independent household variables, the study established a positive causal relationship between household savings and Income. They explained that the results indicated that one rupee increase in income tends to raise household savings by about 0.63 rupees. This is due to the fact that households' capacity to save increases with rise in Income level and with MPS for household saving

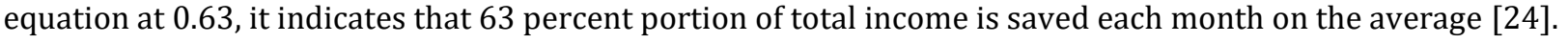

[18] conducted a study on a micro-econometric analysis of household savings in Ghana whose focus was to estimating the likelihood of saving as a function of demographic factors of region, quintile income distribution, location, gender, age, educational level and house size. Applying a Tobit model on cross sectional data from Ghana's Living Standard Survey, it was found that, the rich (as characterised by higher income quintiles) save more than the poor (as characterised by the lowest income quintile). The study thus established that those in higher income quintiles had significant marginal propensity to save more than household's in the first quintile.

Similarly, [25] undertook an investiagtion in Morocco on Households Saving Determinants in Morocco. Using a CBMS survey, it was found that income was an important determinant for household saving both in the case of urban and rural households and further that the saving rate depends positively on household income in rural and urban areas. The results found that a unit increase income household saving increases by 0,07 dirham [25]. Although the magnitude of the impact of income on savings deferred with the results in [18] and [24], the results are consistent in terms of the significance of income in explaining household savings.

In related study by [26] on determinants of household savings in rural areas of Kenya, using the least squares method on a total sample of 359 households, it was found that Household income was significant in explaining the level of saving by the household. The study further observed that the marginal propensity to save out of income ranges from 0.0605 in the case of Teachers to 0.2558 in the case of Businessmen and averages 0.1578 for all households. They concluded that the low levels of savings were as a result of low levels of household incomes. Similarly, the results in [27] on understanding the determinants of household savings found that current income presents a positive and significant impact on savings rate, however, if this income is from the government transfers and remittances, there is a tendency to reduce savings as it was found that higher proportion of government transfers remittances as overall household income, reduced the saving rate.

Household size plays an important role in influencing household savings potential. It is understood that the impact of children on family consumption, and by implication, on savings, depends on their impact on family income and family consumption [28]. It is inarguable that increased family size entails increased consumption expenditure and hence, reduces savings ability. A number of studies have revealed the relationship between these variables. According to the results in [29], the negative statistically significant relationship between family size and saving indicate that increase in family size by one member reduces savings by $0.4 \%$. They added that this was obviously true due to the fact that as family size increases most of the income would be consumed and less would be saved. They concluded that if there is increase in household size then saving will be low and if the size of household is small then the saving will be [29]. The findings by [29] is only true to the extent the household members are non-working members. If the members are working, increased household size is likely to result in increased household income, hence increased household saving.

In another study, [30] investigated the relationship between savings and family size. Using OLS multi regression analysis on 201 households, it was found that there was negative impact of family size on household saving and was statistically significant at 5 percent. They concluded that as a number of dependents rise, saving of the households fall and vice versa and these results were consistent with those found by [29] which found negative significant relationship between savings and family size.

Similarly [31], using cross sectional data from the China Household Finance Survey (CHFS) of 2013 and employing Tobit regression which made savings rate a function of family size, the estimate for the coefficient Children was found to be equals to -0.024 , meaning that household saving rates decrease by about 2 percentage points with each additional child. The other results found Families with no children to support, save over $30 \%$ of their income and estimated that on average; those with more than three children save less than 20 percent. They added that this estimate is practically large and statistically different from zero and further concluded that the estimate for the coefficient factors and Household saving rates monotonically decrease with the number of dependent children [31].The further conclusion from this study was that when using standard parameter values, reducing the number of dependent children from 3 to 1 increases the saving rate by about 10 percentage points and that their empirical findings supported the structural model's predications both qualitatively and quantitatively and life-cycle theory of household saving predicts. 
In accordance with the $\mathrm{LCH}$, age plays a vital role in explaining savings. It is expected that at a certain age, individual savings are expected to increase, attain it maximum and begin to fall in the order age. In empirically investigating the relationship between age and household savings, a number of empirical studies have been undertaken and have been reviewed here.

The results in [26] on the relationship between age and household savings revealed that Age was found to have a negative influence on saving of specifically among the subjects. With the coefficient of age is -51.264 , it means that aging by one year (a year increase in the age of the individual) will result in a decline in household saving by about Shs.51.25 and sign on the age coefficient was in line with their priori expectation. They further concluded that saving by the adult population would be diminishing with age as they grow towards and beyond retirement age. The adult age considered in this case was 30 years. In the study by [27] on data on household savings in Latin America, it was found Age has a positive but decreasing effect on saving. However, they observed that the age coefficient becomes significantly negative when adopting an income-based definition for the dependency ratio, which renders the result of age having a decreasing effect on savings fragile. Further when considering the age-defined dependency ratio (i.e. the sum of old and young), the study revealed a positive sign when controlling for current income, which turns negative for total and young dependency when current income is dropped. However, after changing the current income, the old dependency ratio remains positive and that the same results are found when current income is instrumented.

[32] examined the determinants of the saving behaviour of Visakhapatnam district. Using data from 120 sample households collected from both tribal and rural households and employing the Multiple Regression Model and Logistic Regression Model, the results revealed that the age of the head of the household was significantly influencing the saving behaviour in the District. When using the dependency ratio in the tribal area, it was found that the dependency ratio had severely affected household savings.

[33] analysed the saving behaviour in Kenya. The results found varying savings rate for different age bracket. It was found that household heads within the age bracket of 45-65 years had the highest saving rate of 0.20 and the least saving rate of 0.041-0.60. Further, it was revealed that the household heads in the age brackets of over 65 years had the highest and least saving rate of 0.21-0.40. They attributed the high savings of the 45-65 years households' age bracket to the fact that the household heads were able to save more because they were in their economically active age bracket which view resonated with life-cycle hypothesis that the individuals in their middle age save more than others while their savings decrease as they attain old age [33].

Employment forms the major source of income of individuals. Through employment, individuals increase their consumption through earned income which part of it is saved. Thus, in line with the LCH and the PIH, it is inarguable that employment will greatly influence the savings of the household. The extent to which this is true can dependent upon how the individual views employment in light of income either as the Keynesian argument for current income or the Monetarists argument for permanent income. A number studies have been reviewed and are stressed out here:

[30] on employment status and savings found that employment status of the household head was positive and statistically significant at 5 percent. In their study, they presented employment status with reference variable being selfemployed.

In [34] on employment status and saving for retirement, it was found that only half of self-employed people were contributing to a private pension or saving in some other way for their old age and their multivariate analysis found that, ceteris paribus, self-employed people were only half as likely as employees to be putting money away. It was further revealed that along with others not covered by financial products, the self-employed may view their home as an asset to be used to fund retirement income. Beyond this, the link between retirement saving and being in employ ment was stark.

Relating to employment status is concern for job security as opined by [35]. His study on co-movements of job security perceptions and household saving rates using data from the 1992 to 2010 from the German Socio-Economic Panel, found that higher job insecurity was generally accompanied by slightly lower saving which suggests that employment and financial insecurity typically go hand-in-hand. He added that when confounding changes in the perception of financial security are controlled for, slight evidence for precautionary saving behaviour was found. He concluded that this behaviour is of however small economic importance and limited to households that are somewhat worried about their financial situation who increase their saving by about $0.3 \%$ or EUR 100 annually in the light of increased job insecurity. There was however, contrast as no significant change in saving was observed for households that were either very concerned or not at all concerned about their financial situation, that is to mean they are either financially constrained or in possession of a buffer-stock of wealth [35]. 
Locality or region is believed to affect the savings behaviour of households. For instance, it is believed that for employees on the same salary scale, when employed in two regions i.e. rural and urban, an employee in the rural region will have a higher savings rate as compared to the individual in urban region. A number of studies have investigated the relationship between household savings rate and the locality of the household.

[29] on the effect of locality on household savings, using a sample of 120 respondents drawn from rural and urban areas of Muzaffarabad District in which respondents were randomly sampled and employing OLS multiple regression in which the log of savings was a function of income, total family size, locality and education, it was found that that locality has positive and significant effect on saving, means that if the people move from urban to rural areas their savings will increases due to low consumption as in rural areas relative income and consumption decreases as compare to urban areas [29].

Additionally, [36] investigated the determinants of households' saving in three districts of Pakistan. Using a field survey to collect data through structured questionnaire from 270 respondents in both rural and urban areas of concern districts, it was found that impact of urban nature of the household increases the saving which means that the household in urban regions tended to save more than households in rural areas. These results were consistent with those found by [37] however, they are inconsistent with the results in [29].

\section{Methodology}

The research design adopted for this study was an explanatory design. The study employed cross-sectional secondary data obtained from the 2015 Living Condition Monitoring Survey (LCMS) obtained from the Central Statistical Office. According to [38] the LCMS was conducted in April/May 2015 and covered 12,251 households in 664 randomly selected Enumeration Areas (EAs) across the ten (10) provinces of Zambia namely; Eastern, Central, Copperbelt, Luapula, Lusaka, Muchinga, Northern, North-western, Southern and Western Provinces of Zambia. The study employed both qualitative and quantitative data. The data in the survey incorporated quantitative data as on factors such as income and age while it also included qualitative data on factors such education level, region, employment status, religion among other variables.

\subsection{Model Specification}

In econometrics procedure, it is required that the relationship between variables is expressed as a functional relationship. In this study, the functional relationship was expressed as follows;

$S_{\mathrm{HH}}=f(I N C, E M S, A G E, R G N, H H S)$

Where;

$\mathrm{S}_{\mathrm{HH}}$ is household Savings which is measured by the amount saved by the household

INC is household income which is measured by the earnings accrued to the household

EMS is Employment Status which is measured by the type of employment the household head was engaged in

AGE is Age of the Household head as measured by the number of years from the first birthday

RGN is region (rural or urban) which is measured by the proportion of respondents dwelling in rural or urban areas

HHS is the Household size as measured by the number of members in each household.

The above functional equation was transformed in an econometrics Logistic Regression Equation. The Logistic regression according to [39] is a statistical method for analyzing a dataset in which there are one or more independent variables that determine an outcome. The outcome is measured with a dichotomous variable (i.e. a variable in which there are only two possible outcomes). Thus, the savings logistic regression equation was expressed as below;

$\operatorname{Logit} P(S)=\alpha+\beta_{1} I N C+\beta_{2} E M S+\beta_{3} A G E+\beta_{4} R G N+\beta_{5} H H S+\varepsilon$ 
Where logit $\mathrm{P}(\mathrm{S})$ is the likelihood of saving given the change in the independent variables. According to [39], the logistic regression coefficients $(\beta \mathrm{i})$ show the change in the predicted logged odds of having the characteristic of interest for a one-unit change in the independent variables.

\section{Empirical results}

\subsection{Econometric Data Analysis: The Logit model}

The Logit model is one of the methods that can be used in estimating models where the dependent variable has a binary outcome, the decision to save or not to save. It usually takes on two values, a zero (0) if a given household actually does not save, or a one (1) if a given household does save, as follows:

$\operatorname{Logit} P(S)=\alpha+\beta_{1} I N C+\beta_{2} E M S+\beta_{3} A G E+\beta_{4} R G N+\beta_{5} H H S+\varepsilon$

Where;

Savings $=\left[\begin{array}{l}1, \text { if Yes } \\ 0, \text { if No }\end{array}\right]$

Here, instead of estimating the values of one and zeroes, the model estimated the probability $(p)$ that savings $=1$ as a function of the explanatory variables household income, employment status, age, region and household size. Let $\mathrm{S}$ represent savings and hence,

$P=\operatorname{Lr}(S=1 \mid X)=F\left(X^{\prime} \beta\right)$

Thus the probability of savings $=0$, that is 'no saving' is derived as 1 - $\mathrm{P}$.

Where $f\left(X^{\prime} \beta\right)$ is a cumulative distribution function of the standard normal distribution as;

$f\left(X^{\prime} \beta\right)=\wedge\left(X^{\prime} \beta\right)=\frac{e^{X^{\prime} \beta}}{1+e^{X^{\prime} \beta}}=\frac{\operatorname{Exp}\left(X^{\prime} \beta\right)}{1+\operatorname{Exp}\left(X^{\prime} \beta\right)}$

Such that the predicted Savings Logit Model will be given by;

$L_{\mathrm{r}}\left[S_{\mathrm{i}}=1 \mid X_{\mathrm{i}}=(\right.$ Income, Employment status, Age, Region, Household Size $\left.)\right]$

As, a result, the predicted probabilities are within the values of zero (0) and one (1). The Logit model is estimated by Maximum Likelihood Estimation, and its errors (disturbances) are assumed to follow the standard normal distribution.

\subsubsection{Logit Model Estimation}

Having considered all the above probability distribution, the estimated savings Logit Model is shown in the figure below;

In this study, Variables that determine Household savings were both categorical and ratio scales variables. For this reason, the Logit coefficients are interpreted based on their respective signs and not their magnitudes. The study found a positive relationship between household income and savings. It can be deduced from the study the higher the level of income, the more likely a given household will save. This is in line the Keynesian theory on savings and consumption. The study found that, households with self-employed non-agricultural income and wage non-agricultural income sources are more likely to save than those with self-employed agricultural income sources. With reference to regional location of households, the study adopted the rural area as the reference dummy for comparison and contrast. The Logit result shows that households located in the urban areas are less likely to save compared to those the in rural region. The result of employment status showed that, the probability to save for those in formal employment is higher than those who are informal employment. With regard to age, the study found that age was inversely related to savings in that the probability of a household to save decreased with an additional year of age of the household head. In other words, below a certain age, households tend to save more but as they exceed that age, their savings rate begin to diminish. Further, the study found an inverse relationship between the size of the household and the probability to save. The addition of one extra person to the household tends to decrease the likelihood of a given household to save. 


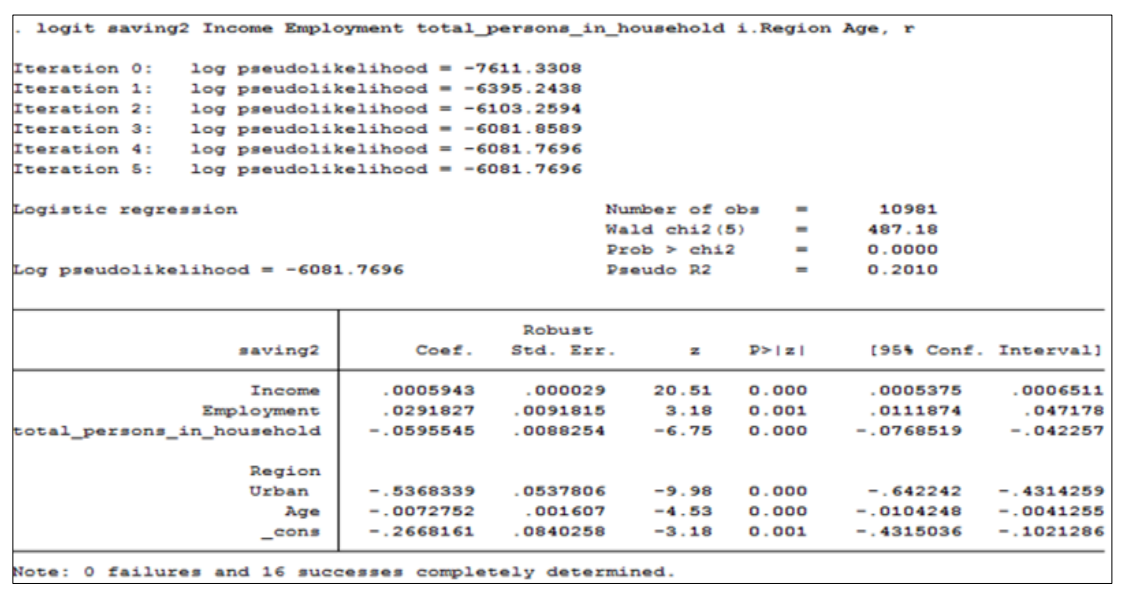

Figure 1 Estimated Savings Logit Model

\subsubsection{The Logit Model Marginal Effects}

In order that the coefficient of the Logit model is interpreted as in the case of the OLS regression, it is required that the Logit equation takes the marginal effects of the independent variable(s) on the dependent variable. According to [40], marginal effects show the change in probability when the predictor or independent variable increases by one unit. For continuous variables this represents the instantaneous change given that the 'unit' may be very small. For binary variables, the change is from 0 to 1 , so one 'unit' as it is usually thought [40]. The Marginal effect for the Logit model is given as below;

$\frac{\partial p}{\partial X_{\mathrm{i}}}=\wedge\left(X^{\prime} \beta\right)\left[1-\wedge\left(X^{\prime} \beta\right)\right] \beta_{\mathrm{j}}=\frac{e^{X^{\prime} \beta}}{\left(1+e^{X^{\prime} \beta}\right)^{2}} \beta_{\mathrm{j}}{ }^{\prime \prime}$

The results of the study on the AME are presented as below

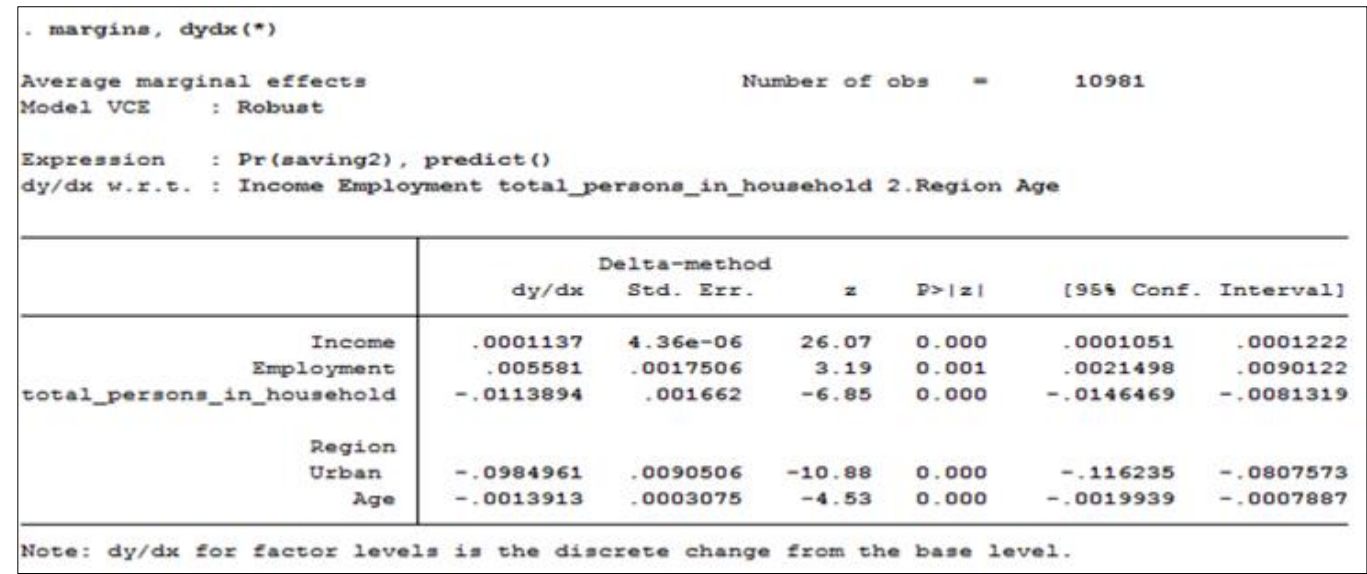

Figure 2 Estimated Average Marginal Effects

The study found a positive relationship and significant relationship between household income and savings. With the income coefficient of 0.0001 , this means that a percentage increase in household income will on average increase the probability of household saving by 0.01 percentage point. It can be deduced from the study the higher the level of income, the more likely a given household will save. This is in line the Keynesian theory on savings and consumption. The results on the income are consistent with those found by [18], [41] on Ghana and [25] on Morocco. Thus, the study supports the Keynesian Relative Income Hypothesis.

With reference to regional location of households, the study adopted rural area as the reference dummy for comparison and contrast. The AME results of the region coefficient of -0.0984 implies that households located in urban areas are $9.8 \%$ less likely to save as compared to rural households. This shows that households located in the urban areas are less 
likely to save compared to those the in rural region. This could be explained by the fact that given fixed income between any two individuals located in urban and rural, the consumption expenditure in urban outweighs the consumption expenditure in rural thereby, rendering the ability of an individual to save in rural higher than the individual in urban as savings is total disposable income less consumption expenditure.

Employment status is expected to have significant impact on household decision to save. The results of the AME on the employment status, with the coefficient of 0.00558 found that the employed were 0.56 percentage point more likely to save than the unemployed. The employment status was further found to be significant. The empirical results show that employment status acts as the source of income for households and that as income was found to significantly affect savings, it was no surprise that employment status significantly affect savings.

With regard to age, the study found that age was inversely related to savings in that the probability of a household to save decreased with an additional year of age of the household head. In terms of the magnitude, with the age coefficient at -0.00139 , the study found that an increase in the age by a year reduces the likelihood of saving by 0.14 percentage point. However, the stage at which increase in Age increases remains critical to establish.

The study found an inverse relationship between the size of the household and the probability to save. With the AME coefficient of -0.0114 , it means that an introduction of an extra member in the household reduces the chance of savings by 1.14 percentage point. The results hold true especially if the extra member introduced in the family is non-income earner. Otherwise, if the introduced member is an income earner, this should lead to increased household savings as noted the conclusion drawn by [27] who indicated the role of income earner in household savings.

\subsubsection{Goodness of fit measures}

To evaluate the goodness of fit for the Logit model, the approach of percent correctly predicted values can be employed. This is similar to the $\mathrm{R}^{2}$ of OLS. The approach is that, if a predicted probability to save is more than 0.5 , it is assumed $\mathrm{S}=1$, otherwise it is assumed $\mathrm{S}=0$. This therefore results in four possible outcomes as presented in the Table below.

Table 1 Goodness of Fit Prediction

\begin{tabular}{|l|l|l|}
\hline Classified & Actual $\boldsymbol{S}=\mathbf{1}$ & Actual $\boldsymbol{S}=\mathbf{0}$ \\
\hline Predicted $\widehat{\boldsymbol{S}}=\mathbf{1}$ & A (True) & B (False) \\
\hline Predicted $\widehat{\boldsymbol{S}}=\mathbf{0}$ & C (False) & D (True) \\
\hline
\end{tabular}

Goodness of fit measures four outcome predictions for the Logit Model presented as below;

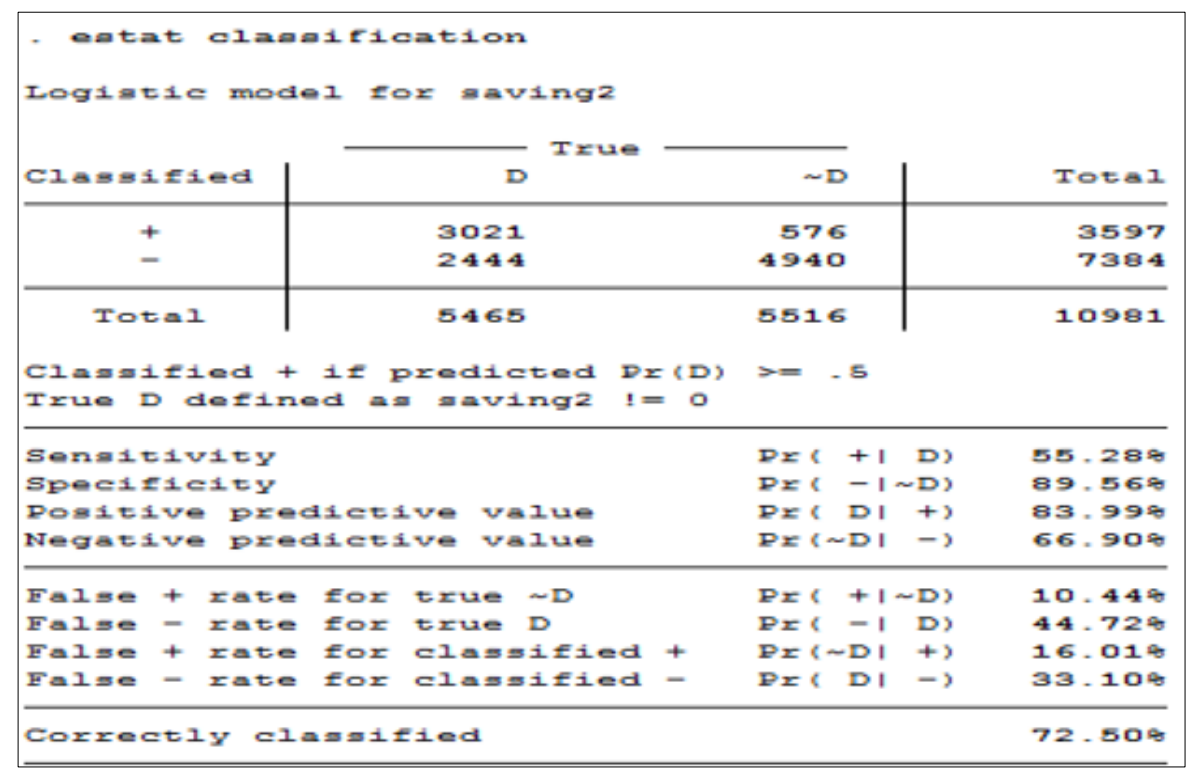

Figure 3 Goodness of Fit Results 
The results of the goodness of fit of the Logit model shows that about 73\% variations in savings are correctly predicted by the independent variables income, age, employment status, region and household size. As the goodness of fit is above $50 \%$, the model remains accepted and empirically valid.

\section{Conclusion}

Arising from the findings highlighted above, it was empirically concluded that increase in income triggers increased investment although the magnitude of the MPS remains unknown. This is true because savings is the postponed consumption. The results further held the Keynesian Relative income hypothesis as the concern for income also led to the conclusion that the positive outcome of increased savings with improved employment status stems from the fact that income earners will save more than non-income earners whether they are saving for precaution or saving for investment.

The study further concluded that the negative significant impact of household size on savings is due to the fact that most household members in Zambia are dependents who are not income earners as there is a culture of income earners in Zambia to have own house and be counted as independent household especially for male income earners. Thus, the additional member in the household entails bloated dependency on the household head who may be the only income earner. This will automatically increase the household expenditure while decreasing savings. On Age, the study concludes that the impact of age on savings cannot easily be explained by the fact that an increase in age will reduce savings. This is because age is expected to move in stages i.e. the stage of early adulthood should be matched by low savings, moving through to the stage of mid adulthood which should see increased savings up to the stage of late adulthood which stage showed be matched with lower savings as the individual should start consuming from the savings in the early and mid-adulthood at least for unbequeathed individual.

\section{Recommendations}

Arising from the finding of this study, it was recommended that;

There is increase sensitization and incentivisation of savings. This can be done encouraging formal employment that would be a saving plan that would pay employees returns on a fixed period say 5 years. It is a well-known fact that while a higher income will increase savings, the higher income may as well affect profitability of the firms and as a result, fewer individuals would remain as income earners which may impact negatively on savings level.

As the rural region as has a higher savings rate than the urban region, savings mobilisation can be enhanced by financial inclusion programmes that will enable rural dwellers to save out of their agricultural economy. Thus, there is need to focus on bringing on board the unbanked rural communities on highly incentivised savings programme.

\section{Compliance with ethical standards}

\section{Acknowledgments}

We would like to thank the Information and Communications University Research Department for valuable support and guidance in producing this work.

\section{Disclosure of conflict of interest}

We wish to assert that this work does not present any conflict of interest.

\section{References}

[1] World Bank. World Development Indicators 2015. Washington DC: The World Bank. 2015.

[2] GRZ. First National Development Plan 1966-70. Lusaka: Office of the National Planning and Development. 1966

[3] McPherson FM. The Consequences of Economic Reforms: Lessons from Zambia. 2006

[4] Anderson P, Bigsten A, Persson H. Foreign Aid, Debt and Growth in Zambia. Uppsala: Nordiska Afrikainstitutet. 2000.

[5] JICA. A Review of FNDP, PDP and DDP Development Processes. Tokyo: Institute for International Co-operation. 2007. 
[6] Chirwa T, Odhiambo N. Macroeconomic Policy Reform and Economic Growth. Euroeconomica. 2016: 1-17.

[7] Adam C, Bevan D, McBrady M. Macroeconomic performance in Zambia 1991-1993 part I: A review of the Rights Accumulation programme 1991-93. 1993. Oxford: Oxford University.

[8] McCulloch N, Baulch B, Cherel-Robson. Poverty, Inequality and Growth in Zambia During the 1990's. Institute of Development Studies. 2000

[9] World Bank. World Development Indicators. Washington D C: World Bank. 2010

[10] Mphuka, C. Are Savings Working for Zambia's Growth? Zambia Social Science Journal, 2010: 175-188

[11] BoZ. Financial Stability: Practice and Strategies. Lusaka: Bank of Zambia. 2018.

[12] IMF. Zambia: Debt Sustanability Analysis IMF Country Report No. 17/327. 25 September 2017.

[13] World Bank. Zambia Development Data. 2019.

[14] Samahiya 0, Okbogor C. Time Series Analysis of the Data of Determinants of Savings in Namibia. Journal of Economics and Sustainable Development. 2014; 5(8): 1-13

[15] Larbi D. The Long run Determinants of Private Domestic Savings in Ghana: a Cointegration Approach. Journal of Economics and Sustainable Development. 2013; 1-13.

[16] Epaphra M. Empirical Investigation of the Determinants of Tanzania's National Savings. International Journal of Economics and Management Science. 2014; 1-9.

[17] Mumba C, Lusaya S. Analyzing the Determinants of Household Savings in Zambia (1985-2017). The International Journal of Multi-Disciplinary Research. 2019; 1-26

[18] Tandoh A. A Micro-econometric Analysis of household Savings in Ghana. Accra: Kwame Nkrumah University of Science and Technology. 2016.

[19] Kagan J. Permanent Income Hypothesis. 14 March 2019.

[20] Wu B. Consumption and Economic Law. Consumption and Management. 2011; 1-11

[21] Froyen T R. Mcroeconomics: Theory and Practices. Upper Saddle River: Prenice Hall. 1999.

[22] Daniels C. Milton Friedman's Permanent Income Hypothesis. 30 June 2011.

[23] Deaton A. The Economics of Savings and Growth: Theory, Evidence and Implication for Policy. Cambridge: Cambridge University Press. 2003.

[24] Rehman H, Faridi, M Z, Bashir F. Households Saving Behaviour in Pakistan: A Case of Multan District.Pakistan Journal of Social Sciences , 17-29

[25] Abdelkhalek T, Arestoff F, De Freitas E, Mage S. (2009, July). A Microeconometric Analysis of Households Saving Determinants in Morocco. 2009.

[26] Kibet K L, Mutai B K, Ouma D, Ouma A. Determinants of household saving: Case study of smallholder farmers, entrepreneurs and teachers in rural areas of Kenya. Journal of Development and Agricultural Economics, 2009; 1(7); 137-143.

[27] Bebczuk R, Gasparini L, Amendolaggine J, Garbero N. Understanding the Determinants of Household Saving: Micro Evidence for Latin America.Plata: Inter-American Development Bank. 2015

[28] Smith J, Ward M. Asset Accumulation and Family Size. Journal of Demography. 1980; 17(3): 243-260.

[29] Abid S, Afridi GS. Assessing the Household Saving Pattern of Urban and Rural Households in District Muzaffarabad.Pakistan Journal of Life and Social Sciences. 2010; 8(2): 137-141.

[30] Syed H, Nigar S, Ullah S. An Analysis of Household Saving and Investment Behavior among Different Income Groups in Urban Area of District Peshawar. iBusiness. 2017; 9: 188-202.

[31] Lugauer S, Ni J, Yin Z. Micro-Data Evidence on Family Size and Chinese Household Saving Rates. 2015.

[32] Gedela S P. Determinants of Saving Behavior in Rural and Tribal Households: An Empirical Analysis of Visakhapatnam District. International Journal of Research in Social Sciences. 2012; 2: 1-14.

[33] Njung'e MP. Gender and Household Savings Behaviour in Kenya. Nairobi: University of Nairobi. 2013

[34] McKay S, Kempson E. Savings and life events. Leeds: Corporate Document Services. 2003. 
[35] Klemm M. Job Security Perceptions and the Saving Behavior of German Households.Ruhr Economic Papers. 2012; 1-36.

[36] Iqbal K, Kurshaid HP, Hafeez M, Danish. Micro Determinants of Household Savings in Rural and Urban Areas: Evidence from Pakistan. International Conference on Management and Operations Research (ICMOR). 2018; 113. Beijing: Research Gate.

[37] Nayak S, Sethi N. Determinants and Pattern of Saving Behaviour in Rural Households of Western Odisha. Rourkela: National Institute of Technology. 2013.

[38] CSO. Living Conditions Monitoring Survey Report. Lusaka: CSO. 2016.

[39] Hosme DW, Lemeshow S, Sturdivant RX. Applied Logistic Regression. New Jersey: John Wiley \& Sons. 2013.

[40] Torres-Reyna, O. Predicted Probabilities and Marginal Effects after Logit/Probit using Margins in Stata. 14 February 2014.

[41] Kodom M. Savings Habit and Use of Savings Among Households in Ga-East Municipality. Accra: University of Ghana. 2013. 